\title{
Geographical Information System (GIS) Application for Planning and Improvement of Public Water Supply in Ota, Ogun State, Nigeria
}

\section{*11UFOEGBUNE, GC; ATANLEY, PA; ERUOLA, AO; MAKINDE, AA; OJEKUNLE, ZO}

\author{
Department of Water Resources Management and Agrometeorology, Federal University of Agriculture, Abeokuta, Nigeria \\ Department of Environmental Management and Toxicology, Federal University of Agriculture, Abeokuta, Nigeria \\ *gidufoes2000@yahoo.co.uk
}

\begin{abstract}
Geographical information system (GIS) technique is a useful tool for spatial analysis which has not been fully exploited in solving water issues in Ota hence the study. The study applied the tool of GIS in the planning and improvement of water supply system in Ota, Ogun state. This study harnessed the synergy of GIS and engineering designs to proffer an acceptable solution to the problems of water supply in the study area. Primary data generated on the field with GPS and spatial information were analysed with the aid of GIS to produce contour pattern and Digital Elevation Model (DEM) in form of maps. The study noted that the population would increase to almost double the present population by the year 2040 invariably resulting to an increase in water demand of the population beyond the capacity of the existing water supply facilities. Results also showed that water demand by the projected population by year 2040 will increase to 68.37 million litres per day while the existing facility has the capacity to produce about 9.2 million litres per day. Maps produced by the study included Contour, Digital Elevation and Existing and proposed pipeline network maps. These maps made available more information which can then be used for improving the water supply system. The study proffered a lasting solution through design of water scheme with capacity large enough to cater for water requirement of the population for the next twenty-five years irrespective of variation in water need of individual residents in the area with designs to improve distribution system through extension of pipelines and identification of various locations for service reservoirs. ( JASEM
\end{abstract}

http://dx.doi.org/10.4314/jasem.v20i4.26

Keywords: GIS, design period, per capita.

Water plays a vital role in the life of both plants and animals; it is one of the most valuable natural resources which nature has blessed man with. Without it, there would be no vegetation on land, no oxygen for animals to breath and the planet will look entirely different than it does today. Water is necessary to keep human body and the environment healthy. Human existence is dependent on accessibility to safe water which can be used for various purposes.

Over the years, people have come to terms with the reality that the little quantity of fresh water (both surface and underground) needs to be well managed because of its none uniform distribution on earth. Access to piped water has been a significant factor in health improvements in most developing regions. As opposed to other water sources, piped water can provide water to homes, plots and yards, and is thought to be the safest drinking water source, provided that the pipes are maintained to ensure water quality (WHO 2010).

In Nigeria, water availability controls population distribution (Ayoade, 1983; 1988), though the pattern of water supply varies from one settlement to another. On average, urban households have more piped water coverage than rural households, but large inequities exist between and within cities. Generally as the population of a settlement increases, the service efficiency to the expanding population decreases. This usually creates a great disparity in supply to different zones of the settlement, thus necessitating the continual monitoring, improvement of the system and expansion of the existing water distribution network.

Ota is a fast growing town at the fringe of Ogun state. The growth of the town is majorly as a result of migration of people from Lagos; a highly congested state. Other factors which control its population include: large expanse of land available for residential purpose, the availability of market and the presence of industries which offer a great deal of job opportunities. Water supply system in Ota has become ineffective due to the rapid increase in population without corresponding provision of water supply structure which meets the daily water demand of the population thus indicating the need for a proper planning of water supply system in the area.

Water is the most abundant element on earth, so one should not expect scarcity or shortage of water on any part of the world but poor accessibility to portable water still remains a major concern especially in urban areas due to poor public water supply system. Most part of the area covered by this study do not have access to public water supply as a 
result of opening up of new sites due to high influx of people to the environment, and several damages done to distribution pipelines during road expansions and bridge construction in Sango area.

Geographical information system (GIS) technique is a useful tool for spatial analysis which has not been fully exploited in solving water issues in Ota as at the time of this project. Introduction of GIS to finding a lasting solution to shortage/ scarcity of water in Ota would make the project worth the while as it would give a new dimension to how such problem can be solved.

Study area: Ota is a town in Ogun state with an estimated population of 163,783 (according to 2006 census). Its total land area is about $878 \mathrm{~km}^{2}$ and it is headquarter of Ado-Odo/Ota local government area. As of 1999, Ota has the third largest concentration of industries in Nigeria. It also possesses a large market and an important road junction, found just north of the tollgate on the Lagos-Abeokuta expressway. The indigenes are predominantly Yoruba of the Awori dialect group. The main occupation of Ota residents is trading and farming. The proximity of the town to Lagos and Idiroko has led to the creation of two large markets: Kayero market in Sango and Oba T.T Dada along Idiroko road. These markets are so large that they blended together and are more referred to as Sango-Ota market. Being part of Ogun state, Ota possesses the same geologic characteristics with many other parts of the state having the basement complex rock and the pre-Cambrian age which are made up of the older and younger granites in the northern part of the state, and the younger and older sedimentary rock in the tertiary and secondary ages in the southern parts (Iloeje, 1981). The region possesses climate of tropical rain-forest with two main climatic conditions; the rainy season which last for between seven and eight months between April and October with an interruption in August, and the dry season running through November till February. The rainfall experienced is usually more than 90 days. The climate is humid because of all the rainfall which amount to about $250 \mathrm{~cm}$ in a year. Due to its closeness to the equator, the region is very hot and wet with an average temperature of not less than $18^{0} \mathrm{C}$ for all the months throughout the year.

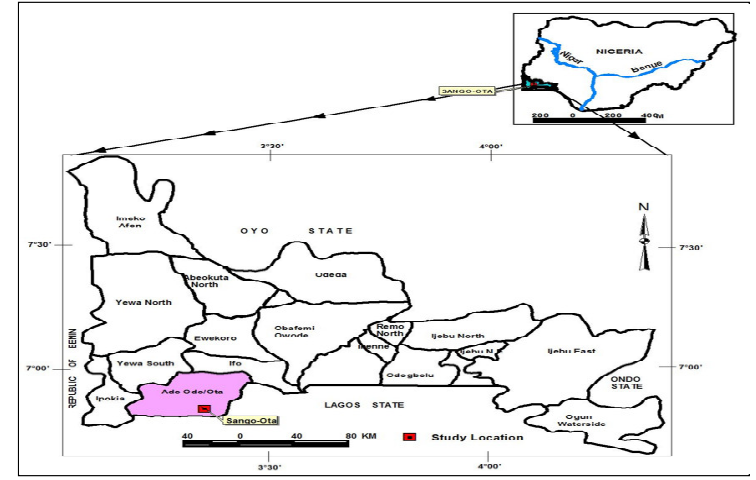

Fig 1: Ogun state showing location of Sango-Ota in Ado-Odo/Ota

\section{MATERIALS AND METHODS}

In this project, a design period of 25 years was assumed; the design date was taken to be 2015 with 80 litres of water adopted for per capita per day consumption. For easy computation of the result, the study area was partitioned into five (5) axes so that each axis can be treated as a unit entity. These areas include: Ijoko, Oju-Ore, Okede, Ilogbo and Toll-gate. The quantity of water to be supplied to meet the water consumption of the population per day was calculated using the information obtained about the population and the growth rate from national population census (NPC 2006). Assumptions necessary to enhance a nearly accurate estimation of the population were made. The total volume of water needed daily was thus calculated through multiplication of the population (population computed from the equation) by the quantity of water consumption per person per day.

The population of Ota for year 2015 and 2040 was calculated using the compound growth rate equation.

$\mathrm{P}_{\mathrm{n}}=\mathrm{P}_{\mathrm{o}}(1+\mathrm{r} / 100)^{\mathrm{n}}$

$\mathrm{P}_{\mathrm{n}}=$ Projected population for $\mathrm{nth}$ year

$\mathrm{P}_{\mathrm{o}}=$ Initial population figure

$r=$ Growth rate $=3.18 \%$ (source: NPC 2006)

The population of Ota as at 2006 according to NPC figure was 163,783. 
The population in 2015

$\mathrm{P}_{2015}=163,783(1+3.18 / 100)^{9}$

The population by 2040

$\mathrm{P}_{2040}=163,783(1+3.18 / 100)^{34}$

\section{Water demand}

Per capita per day consumption $=80$ litres

Assumed safety factor $=1.5$

The safety factor covers for water losses at intake, pipe damage, and reservoirs overflow e.t.c

The average daily demand of the population per day = population $\mathrm{x}$ per capital per day consumption $\mathrm{x}$ safety factor

Maximum water demand $=1.2 \mathrm{x}$ Average daily demand

Maximum water demand for the year $2015=217,084 \times 80 \times 1.5 \times 1.2$

Maximum water demand for the year $2040=474,806 \times 80 \times 1.5 \times 1.2$

Areas un-served with portable water supply were identified through comparison of the map showing existing pipeline with areas it covers on the topographic map.

For generation of an improved distribution plan, the road network from Google earth imagery and the existing pipeline plan of the area of study were scanned and imported into GIS environment using arc-view software for analysis to generate a new distribution pipeline plan for the environment. Primary data was generated from the field with Global positioning system (GPS), imputed into excel office and transferred to GIS environment to generate contour and digital elevation. Positions suitable for citing service reservoir were thus identified from the most elevated parts of the environment.

\section{RESULTS AND DISCUSSION}

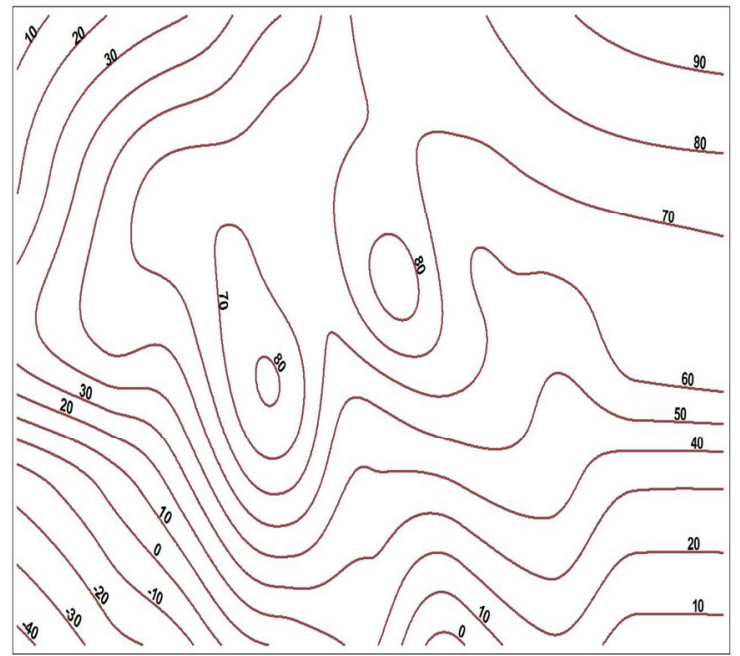

Fig 2: Contour pattern of the study area
The number of pipes to be used for transmission of water to the new environments needing extension of supply pipeline was estimated through division of the total horizontal distances calculated from the proposed pipeline plan by average length of a pipe which is $6 \mathrm{~m}$. The number of sluice valve to be used at points of change in direction of the supply line due to cross-roads and major junctions on the new distribution pipeline was also estimated. Areas with reasonable accessibility were identified and earmarked along the supply pipeline for citing hydrants for fire-fighting. Hydrants would be cited on both the existing and the new pipeline.

Planning for intake, treatment, and distribution of portable water to Ota 


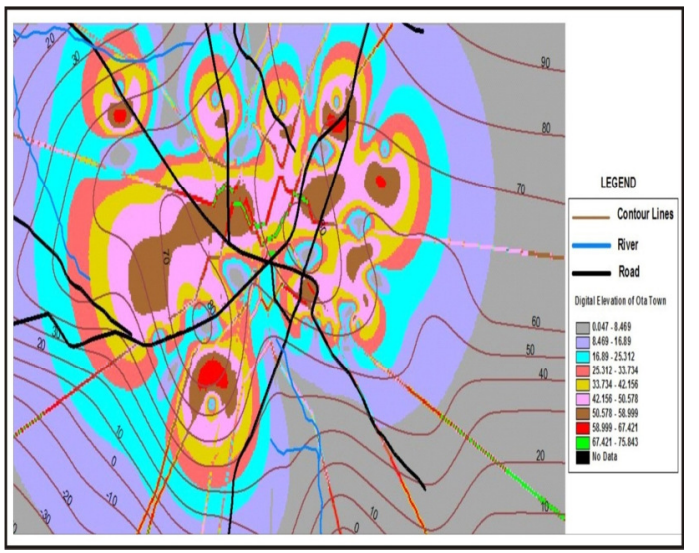

Fig 3: Digital elevation Model

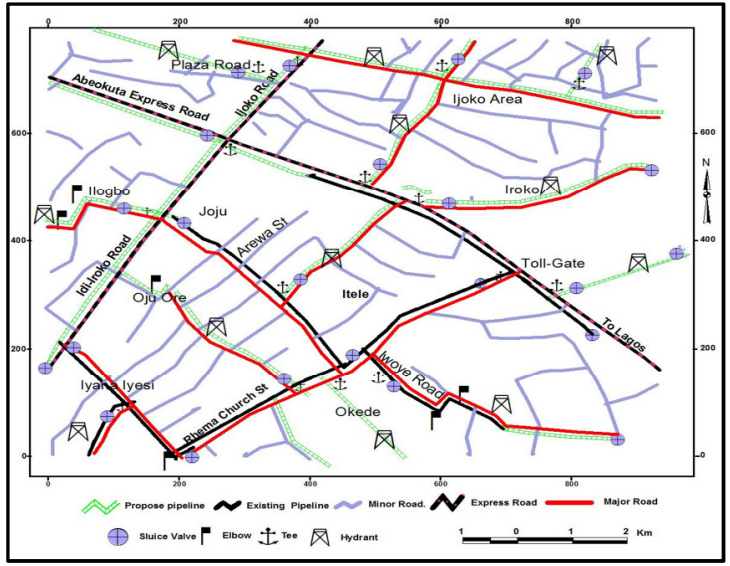

Fig 4: Existing and proposed pipeline network

Figure 2 showed that the area has a relatively flat terrain with gentle slope. The most elevated part of the area is located at the centre and towards the left upper part of the map. Figure 3 showed the combination of contour lines, rivers, major roads and an overview of variation in elevation. Areas having elevation above $75 \mathrm{~m}$ are suggested for citing service reservoirs for proper distribution of water to all homes with sufficient pressure head with the use of sluice valve that help in diversion without or with the need for provision of booster stations.

Figure 4 showed that not all part of the study area are covered by the existing distribution pipelines which are represented by thick black lines. The proposed extension to the existing distribution pipelines are represented with green colour, while necessary location for citation of other accessories such as hydrants, sluices valves, elbows and Tees also represented on the map.

Table 1: showing result of number of pipe and appurtenances needed in each axis

\begin{tabular}{|c|c|c|c|c|c|c|c|c|}
\hline $\begin{array}{l}\text { Area } \\
\text { (axis) }\end{array}$ & $\begin{array}{lr}\text { Total } & \text { Length } \\
\text { of } & \text { Trunk } \\
\text { mains } & \\
(\mathrm{km}) & \end{array}$ & $\begin{array}{l}\text { Total Length } \\
\text { of service } \\
\text { mains } \\
(\mathrm{km})\end{array}$ & $\begin{array}{l}\text { No of Trunk } \\
\text { mains }\end{array}$ & $\begin{array}{l}\text { No of } \\
\text { service } \\
\text { mains }\end{array}$ & $\begin{array}{l}\text { Number of } \\
\text { hydrant }\end{array}$ & $\begin{array}{l}\text { Sluice } \\
\text { valve }\end{array}$ & Tee & $\begin{array}{r}\text { Elbow } \\
\left(90^{\circ}\right)\end{array}$ \\
\hline Ijoko & 25.2 & 25.6 & 4,200 & 4,267 & 4 & 7 & 7 & - \\
\hline Oju-ore & 14.4 & 33.0 & 2,400 & 5,500 & 4 & 6 & 4 & 2 \\
\hline Ilogbo & 5.6 & 10.0 & 934 & 1,667 & 1 & 2 & 1 & 2 \\
\hline
\end{tabular}


Table 2: showing estimated population for year 2015 and 2040

\begin{tabular}{ll}
\hline Year 2015 & 217,084 \\
\hline Year 2040 & 474,806 \\
\hline
\end{tabular}

Table 3: showing maximum daily water demand for the estimated population in various units.

\begin{tabular}{lllll}
\hline $\begin{array}{l}\text { Maximum Water } \\
\text { demand }\end{array}$ & $\begin{array}{l}\text { Million Litres/ } \\
\text { day }\end{array}$ & $\mathrm{m}^{3} / \mathrm{hr}$ & $\mathrm{m}^{3} / \mathrm{min}$ & $\mathrm{m}^{3} / \mathrm{s}$ \\
\hline 2015 & 31.26 & 1302.51 & 21.75 & 0.36 \\
2040 & 68.37 & 2848.75 & 47.48 & 0.79 \\
\hline
\end{tabular}

Table 4: showing the deficit in water demand for the year 2040 in various units.

\begin{tabular}{lllll}
\hline Water demand & Litres/day & $\mathrm{m}^{3} / \mathrm{hr}$ & $\mathrm{m}^{3} / \mathrm{min}$ & $\mathrm{m}^{3} / \mathrm{s}$ \\
\hline 2040 & 59.17 & 2465.42 & 41.09 & 0.68 \\
\hline
\end{tabular}

Table 1 showed the number of different pipes needed to effectively transmit public water to various point of the study area. The result on table 2 showed that the population of the study area will increase from 217,084 in the year 2015 to 474,806 in the year 2040 resulting in an increase of about 257,722 people.

The figures from the table 3 showed that water demand by the projected population by year 2040 will increase to 68.37 million litres per day. The existing facility has the capacity to produce about 9.2 million litres per day provided the scheme at IloAwela has been rehabilitated. This project used the assumption that rehabilitation of the scheme at IloAwela would have been made before the projected year, thus leaving a deficit of 59.17 million litres per day in water demand by the population.

The tables below show the result of designs for the intake, treatment and transmission/distribution works

Table 5: showing details of the intake /waterworks

\begin{tabular}{lllccccc}
\hline Intake/waterworks & $\begin{array}{l}\text { Number } \\
\text { of pipes }\end{array}$ & $\begin{array}{l}\text { Discharge } \\
\left(\mathrm{m}^{3} / \mathrm{s}\right)\end{array}$ & $\begin{array}{c}\text { Velocity } \\
(\mathrm{m} / \mathrm{s})\end{array}$ & $\begin{array}{c}\text { Area } \\
(\mathrm{m})\end{array}$ & $\begin{array}{c}\text { Diameter } \\
(\mathrm{m})\end{array}$ & efficiency & $\begin{array}{l}\text { Power input } \\
(\mathrm{HP})\end{array}$ \\
\hline Intake pipe & 1 & 0.68 & 1.2 & 0.57 & 0.85 & - & - \\
Low lift pump & 1 & - & - & - & - & 75 & 400 \\
\hline
\end{tabular}

Table 6: showing specifications of units in the treatment works

\begin{tabular}{|c|c|c|c|c|c|c|c|c|}
\hline Treatment work & $\begin{array}{l}\text { No of } \\
\text { tank } \\
\text { needed }\end{array}$ & $\begin{array}{l}\text { Detention } \\
\text { time } \\
(\mathrm{min})\end{array}$ & $\begin{array}{l}\text { Area } \\
\left(\mathrm{m}^{2}\right)\end{array}$ & $\begin{array}{l}\text { Discharge } \\
\left(\mathrm{m}^{3} / \mathrm{s}\right)\end{array}$ & $\begin{array}{l}\text { Volume of one } \\
\text { Tank }\left(\mathrm{m}^{3}\right)\end{array}$ & $\begin{array}{l}\text { Depth } \\
\text { (m) }\end{array}$ & $\begin{array}{l}\text { Diameter } \\
(\mathrm{m})\end{array}$ & $\begin{array}{l}\text { Dimension } \\
(\mathrm{m}) \mathrm{x}(\mathrm{m})\end{array}$ \\
\hline Aerator & 2 & 2 & 20.55 & 0.68 & 41.09 & 2 & - & $5.85 \times 3.50 \times 2$ \\
\hline Solution tank & 1 & - & - & 0.015 & 1.05 & - & - & $0.2 \times 0.2 \times 0.4$ \\
\hline Flash mixer & 1 & 2 & 82.18 & - & 82.18 & 1 & - & $9.10 \times 9.04 \times 1$ \\
\hline Clarriflocculator & 2 & 42 & 287.63 & 0.68 & 862.89 & 3 & 19.13 & - \\
\hline Settling tank & 2 & 240 & 1,020 & 0.34 & 4,896 & 4.8 & 36 & - \\
\hline Filter tank & 15 & - & 12,327 & - & - & 1.9 & - & $27.34 \times 30.06 \times 1.9$ \\
\hline Clear water well & 2 & 240 & $1,232.71$ & - & $4,930.84$ & 4 & - & $30.02 \times 41.09 \times 4$ \\
\hline
\end{tabular}

Table 6: showing design parameters for transmission works

\begin{tabular}{lcccccc}
\hline Transmission works & Diameter $(\mathrm{m})$ & $\begin{array}{c}\text { Velocity } \\
\left(\mathrm{m}^{2} / \mathrm{s}\right)\end{array}$ & Number & $\begin{array}{c}\text { Volume } \\
\left(\mathrm{m}^{3}\right)\end{array}$ & $\begin{array}{c}\text { Depth } \\
(\mathrm{m})\end{array}$ & $\begin{array}{c}\text { Surface area } \\
\left(\mathrm{m}^{2}\right)\end{array}$ \\
\hline High-lift pump & - & - & 2 & - & - & - \\
Trunk main & 0.34 & 1.5 & 5 & - & - & 0.091 \\
Service reservoir & 24.55 & - & 5 & 4733.6 & 10 & 473.36 \\
Gravity main & 0.3 & 2 & 5 & - & - & 0.068 \\
\hline
\end{tabular}

At the water works, selection of appropriate conduit pipe was made, taking into cognizance the volume of water it must convey per second as well as the water velocity.
The result on table 5 showed that one intake conduit pipe of $850 \mathrm{~mm}$ diameter and one low lift pump of $400 \mathrm{HP}$ is required at the intake/ water works. 
The result on the table 7 showed that at the transmission works, two (2) high lift pump of 1000 HP each is needed for transmission of treated water from the treatment works. One pump will be used at a time for transmission of water while the other pump will serve as a substitute to ensure continuity of supply in case there is mechanical fault on one of the pumps. Five (5) trunk mains of diameter $340 \mathrm{~mm}$ each will be needed to transmit water from the clear water well in treatment works to the services reservoirs located at various point within the study area.

In order to facilitate adequate supply of water to all ends of the study area, five (5) service reservoirs each having the capacity of $4733.6 \mathrm{~m}^{3}$ will be erected at some elevated positions across the town so as to ensure free flow of water under gravity. One (1) gravity main of about $300 \mathrm{~mm}$ in diameter is recommended at each of the service reservoirs to convey water to the distribution system. For the purpose of this study asbestos pipe of diameter 340 $\mathrm{mm}$ is recommended for trunk mains for conveyance of water from service reservoir while service mains of $150 \mathrm{~mm}$ diameter will be used for the distribution system in each axis

The result showed that the population will increase to more than twice the present population by the year 2040. As a result of this increase in population, the maximum quantity of water demand will increase to about 68.37 million litres per day. This is similar to the finding of Ufoegbune et. al (2011) in Oyo metropolis which states that the maximum water demand by the population would increase from 1.13 million litres per day in 2010 to 1.86 million litres per day by 2030 . The wide margin between the capacity of the existing structures and the quantity of water demand by the present population shows that the existing facilities has elapse its design period and can no longer cater for the present daily water demand of the people which is about 31.26 million litres per day. Ufoegbune et.al (2010) attributed the problem of insufficient water supply to an increase in volume of water demand due to an increase in population beyond the design capacity of the water schemes, poor funding of water sector and lack of maintenance culture which is usually responsible for the frequent breakdown of water supply facilities resulting to poor water distributions.

In planning water supply system in any locality, it is of utmost importance to estimate the population to be served, the maximum quantity of water an individual uses daily and determination of population growth (A manual for field staff and practitioners, 2009). For adequate and constant provision of water to meet the daily demand throughout the design period, design of low lift pump, high lift pump and conduit pipes was made for effective conveyance of raw water from the source to the treatment work and for transmission of treated water to various parts of the town; specifications of various units required for purification was also made making assumptions where necessary.

Conclusion: Adequate planning of social amenities such as water supply, roads, electricity etc is a necessity for continuous growth and development of every society especially when there is likelihood of increase in population. Out of all these social amenities, water supply is the most vital and essential to well being of people; having its relevance in health, food production, economic, and environment.

Despite the numerous contribution of water to overall well-being of people, many residents in Ota still do not derive maximum benefit from this resource due in large to lack of access to public water supply in time and space. The growth rate of population and stoppage of work at the water scheme at Ilo-Awela are among the factors contributing to shortage and unavailability of water supply in some areas. Poor planning of distribution system which led to destruction of some pipes along distribution network during roads and bridge construction in Sango area resulting in non functionality of reservoirs at IyanaJoju, and Sango is another major factor.

Planning for water supply of any community involves paying keen attention to per capita per head as well as the expected population the designed system is to serve. In this project, it was revealed that population of Ota would increase to almost twice the present population by the year 2040. Failure to make adequate provisions for water supply will tremendously increase the struggles of residence to have access to water. Also public health may be adversely affected as water demand will far outweigh its supply resulting into poor hygiene/sanitation.

To this end, this project proffer a lasting solution through design of water scheme with capacity large enough to cater for water requirement of the population for the next twenty-five (25) year irrespective of variation in water need of individual residents in the area. GIS technique was also employed to improve distribution system through extension of pipelines and identification of various locations for service reservoirs. Area identified for this purpose include: Oju-Ore, Otun, Ilogbo, Ijoko, and Onibuku.

In light of this, it is therefore concluded that full implementation of solutions proffered in this work 
would not only ensure regular water supply in time and space to all ends of Ota, but also afford residents a quality and healthy lives necessary to thrive in their daily

Recommendations: It is recommended that: study should be done on quality assessment of water sources for the proposed scheme. A study which will lead to identification of suitable location for the proposed water scheme should be carried out.Government policy which will review water distribution system beyond the design period be put in place.

\section{REFERENCE}

Ayoade J.O (1983), Introduction to Climatology for the Tropics. John Wiley, Chinchester.

Ayoade J.O (1988). Tropical Hydrology and Water Resources

Iloeje, N.P. (1981): A New Geography of Nigeria. New Revised Edition, Longman, Great Britain.

The World Water Organization, (2010), "Water Facts \& Water Stories from Across the Globe," Accessed June 16, 2010. http://www.theworldwater.org/water_facts.php

The World Water Organization,(2010), "Water Facts \& Water Stories from Across the Globe," Accessed June 16, 2010. http://www.theworldwater.org/water_facts.php
Ufoegbune G. C, Oparinde O. C, Eruola A. O, (2011), Municipal water supply planning in Oyo metropolis, Oyo state south western Nigeria: journal of Geography and regional planning Vol. 4(7), pp 392-400.

Ufoegbune G.C., Oyedepo J., Awomeso J.A., Eruola A.O. (2010). Spatial Analysis of Municipal Water Supply in Abeokuta Metropolis, South Western Nigeria, REAL CORP Proceedings/Tagungsband Vienna, 18-20 May 2010.

Ufoegbune, G. C.1, Orimoloye, A. O.1, Eruola, A. O.1 and Ogunyemi, I. O. (2011), The economics of water supply management in Obantoko area, Abeokuta, Nigeria: Journal of Geology and Mining Research Vol. 3(6), pp. 153-160, June 2011 Available online http://www.academicjournals.org/jgmr ISSN 2006 - 9766 @2011 Academic Journals

World Water Assessment Programme, (2009), Water in a Changing World: UN Water Development Report 3

World Health Organization (WHO) and United Nations Human Settlements Programme (UNHABITAT), (2010), Hidden Cities: Unmasking and Overcoming Health Inequities in Urban Settings. 